\title{
RETHINKING TECHNOLOGICAL LEARNING SPACES FOR EFFECTIVE TEACHING AND LEARNING IN HIGHER EDUCATION INSTITUTIONS: A PERSPECTIVE FROM SOUTH AFRICA
}

\author{
Sunday Olawale \\ Olaniran $^{1+}$

\section{Mncedisi Christian} \\ Maphalala $^{2}$
}

\author{
${ }^{1,2}$ University of Zululand, Faculty of Education, Department of Curriculum \\ and Instructional Studies, University of Zululand, South Africa. \\ Email:olaniransundavo@gmail.com Tel:+270359026702 \\ 'Email:MaphalalaM@unizulu.ac.za Tel: +270359026702
}

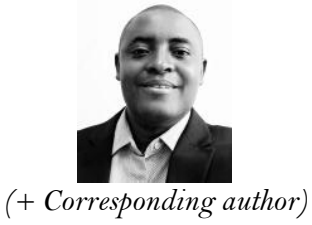

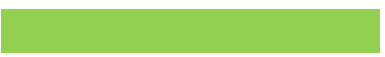

Article History

Received: 10 August 2020 Revised: 18 September 2020 Accepted: 5 October 2020 Published: 16 October 2020

\section{Keywords}

$4 \mathrm{IR}$

Case study

COVID-19

Earning spaces

Higher education

South Africa

Teaching and learning

Technology

\begin{abstract}
The emergence of learning technology in higher education is an interesting phenomenon that continues to gain acceptance. While South Africa is regarded as one of the leading African nations with quality higher education, there is a need for her tertiary institutions to fortify their technological learning spaces to meet the needs of today's upwardly-mobile higher education students. This study adopts a single case qualitative study design in the form of a survey to examine the state of technological learning spaces in a comprehensive university. The actual data for the study was collected from eight (8) academic staff in a rural-based university in South Africa. Data were collected through focus group interviews to allow for rich descriptions of the true state of technological space of learning in the institution. The data were analyzed using thematic analysis. The main variables of technological learning spaces were broken down into sub-themes to address key research issues raised in the study. The findings revealed that though technological facilities such as Wi-Fi internet services, computer laboratory, and Learning Management System (LMS) are available in the institution, some factors are constraining the staff and students from effectively utilizing of these technologies. The study recommends adequate funding/investment, as well as a partnership between the rural based institutions and the universities of technologies in South Africa, as key steps in repositioning the institution's technological space towards teaching and learning needs of the 21 st century higher education students.
\end{abstract}

Contribution/Originality: This study contributes to a dialogue about the state of technological learning spaces in rural-based universities, and the need for a paradigm shift for better teaching and learning delivery. It takes the bold initiative to recommend a partnership between rural based institutions and technological universities in South Africa as a synergy.

\section{INTRODUCTION}

The introduction of technology usage in teaching and learning is undoubtedly a remarkable phenomenon in higher education. Institutions of higher learning worldwide are gradually moving from traditional classroom teaching and learning to technology-mediated learning, with emphasis on the flexibility of learning and learners' autonomy (Ma'arop \& Embi, 2016; Okaz, 2015; Tikadar, Bhattacharya, \& Tamarapalli, 2018). The reason is simple; the recent outbreak of COVID-19 pandemic that resulted in the indefinite school closure is encouraging the massive deployment of technology to facilitate teaching and learning. The Fourth Industrial Revolution (4IR) has been described as one that would bring massive disruption to different sectors of the global economy, including higher 
education (Butler-Adam, 2018; Ngcamu, 2019; Selamat, Alias, Hikmi, Puteh, \& Tapsi, 2017). One of the obvious disruptions that 4IR is bringing to the higher education landscape is the use of sophisticated technologies to facilitate teaching and learning (Butler-Adam, 2018). Academic activities cannot be efficient where "both academic and non-academic staff members' technological skills are neither non-existing nor obsolete” (Ngcamu, 2019). Hence, there is a need for higher education institutions to provide effective digitalized learning environments and technologies. Such technological environments will not only foster effective teaching and learning but also prepare students for the digital skills expectation of the 4IR labor market.

The core assignment of universities remains the same no matter the revolution or trend in the society. Universities worldwide are established to perform three core functions - teaching, research, and community service (Keerberg, Kiisla, \& Mäeltsemees, 2013). Specifically, the main objective of any university is to provide quality teaching and learning, bring students closer to how knowledge is created through research, and to contribute to societal development through community service. While giving credence to the developmental roles of universities' research and community service, teaching could be seen as the most vital. This is because of its capacity to produce the next generation of researchers and community development agents.

The South African government's national education plan in terms of Action Plan 2014 (DoBE, 2014) acknowledged the quality of teaching as fundamental to improving students' learning. While there is a broad consensus on the importance of effective teaching to student learning, there is a dearth of research on how institutional technology space impact students' learning and the efforts South African higher institutions are making to ensure that pre-service teachers have access to the right technological learning environment to equip them with the necessary skills, knowledge, and competencies to deliver quality teaching using learning technology after graduation. It is on this premise that this study seeks to examine the current technological spaces for teaching and learning in South African higher institutions to identify how they are enabling and/or constraining teaching and learning activities in the institution, using the case study method for a rural-based university in the country.

\subsection{Technological Space in Higher Education}

The higher education landscape is changing rapidly due to the changing nature of the society (Pucciarelli \& Kaplan, 2016). The advancement of Information and Communication Technology (ICT) has brought tremendous disruptions in the way higher education institutions conduct their core activities, including teaching and learning, research, and community service. E-learning technology has become the major driving force for teaching and learning in higher education today (Duvivier, 2019). Globally, higher education institutions have not only designed relevant curriculum and pedagogy, but also built strong technology to drive it. With the current trend of the massification of higher education globally, the well-being or functionality of any higher education institution will not be determined by its sophisticated physical classrooms and library facilities, but how strong it is technologically. The term 'technological capabilities,' is used by Lall and Kraemer-Mbula (2005) and Olaniran, Duma, and Nzima (2017) to draw the attention of higher education institutions to the need to build strength in their technological spaces. It is stressed upon that technological competence or development cannot be achieved unless making any effort to acquire, adapt and develop upon existing technologies (Lall \& Kraemer-Mbula, 2005). This implies that higher education institutions must be willing and deliberate to invest in their technological space for teaching and learning activities to be meaningful.

Learning space, be it physical or technological, can have a significant impact on student learning (Marais, 2016; Ng'ambi, Brown, Bozalek, Gachago, \& Wood, 2016). Technological space is an umbrella term to represent the varieties of technologies put together to drive effective teaching and learning. These include the hardware and software technologies ranging from Wi-Fi internet services to the Learning Management System (LMS). Unlike the traditional physical spaces that are mostly constraining and immovable, technological space fosters teaching and learning without the barriers of distance, time and space. McLoughlin and Lee (2008) note that many higher 
education institutions are realizing the need to adopt new technologies and models of teaching and learning to meet the needs of today's generation of students who seek learning flexibility and greater autonomy, as well as enabling platforms for socio-experiential learning and networking. A strong technological space enables wide sharing of knowledge and ideas by disrupting the traditional learning status-quo and bridging the gap between students, teachers and institutional authorities. McLoughlin and Lee (2008) emphasized further on the uniqueness of technological space by analyzing its deliverables:

Tools like blogs, wikis, media-sharing applications and social networking sites can support and encourage informal conversation, dialogue, collaborative content generation, knowledge sharing, learners to have access to a wide range of ideas and representations. If used appropriately, they make truly learner-centered education a reality by promoting learner agency, autonomy, and engagement in social networks that straddle multiple real and virtual communities by reaching across physical, geographic, institutional, and organizational boundaries.

In South Africa, the massification of higher education is already mounting pressure on the available physical learning spaces (Mohamedbhai, 2008; Sosibo, 2019). Limited numbers of lecture halls and residences are available to serve a large population of students admitted yearly. Investment in learning-technologies has been proposed as a solution to this problem (Gandhi, 2018; Lemmens \& Henn, 2016). Moreover, Punie (2007) suggests that higher education institutions should consider strengthening their technological learning spaces by paying attention to Internet access to facilitate learning opportunities and a strong Learning Management system to manage teaching and learning in higher education systems.

The integration of ICT into teaching and learning by higher education institutions globally has made strong on-campus internet access very crucial for students' success, and the overall well-being and development of any institution. Internet access much depends upon smooth internet connectivity which fuels most of the technological learning spaces that are available today. Without access to strong internet facilities, students would be excluded from numerous learning opportunities provided online through internet-enabled platforms. Both positive and negative effects have been recorded concerning internet access and use by higher education students (Garcia et al., 2008; Gutenberg, 2019; Servidio, 2017). For instance, higher education institutions cannot afford uninterrupted internet facilities and provision for efficient and reliable internet connectivity for both students and staff.

The current vogue and demand for electronic learning (e-learning) system has shifted the attention of many higher education institutions from building more traditional physical classrooms. Learning Management Systems (LMSs) are now used globally to facilitate and manage teaching and learning in higher education systems (Aldiab, Chowdhury, Kootsookos, Alam, \& Allhibi, 2019; Reid, 2019). Learning Management System (LMS) is an umbrella term used for "a wide range of system that organizes and provides access to online learning services for students, teachers, and administrators" (Aldiab et al., 2019). Examples of the commonly used LMSs are Moodle, Canvas, Blackboard, skill soft, and NovoEd, among others. Additional online learning platforms like Wiki and blogs are also becoming a major learning and communication platforms for higher education students. While the introduction and wide adoption of LMS by higher education institutions have been applauded globally, Brown, Dehoney, and Millichap (2015) opine that today's LMS needs to be augmented with a new digital framework to accommodate the current transitions in higher education globally, as influenced by the 4IR skill-set demand. However, LMS utilization for teaching and learning has many implications for enhancing as it creates room for archiving learning materials and content sharing between facilitators and students.

\section{THEORETICAL FRAMEWORK}

\subsection{Technology, Organization and Environment (TOE) Model}

The Technology-Organization-Environment (TOE) framework has been a useful tool in understanding how institutions embrace technological innovations to advance their core services, especially teaching and learning. 
Developed in 1990 by Tornatzky and Fleisher, TOE depicts that the process and condition by which an organization or institution adopts and implements technological innovations is motivated by three main perspectives: technological context, organizational context, and environmental context as illustrated in Figure 1.

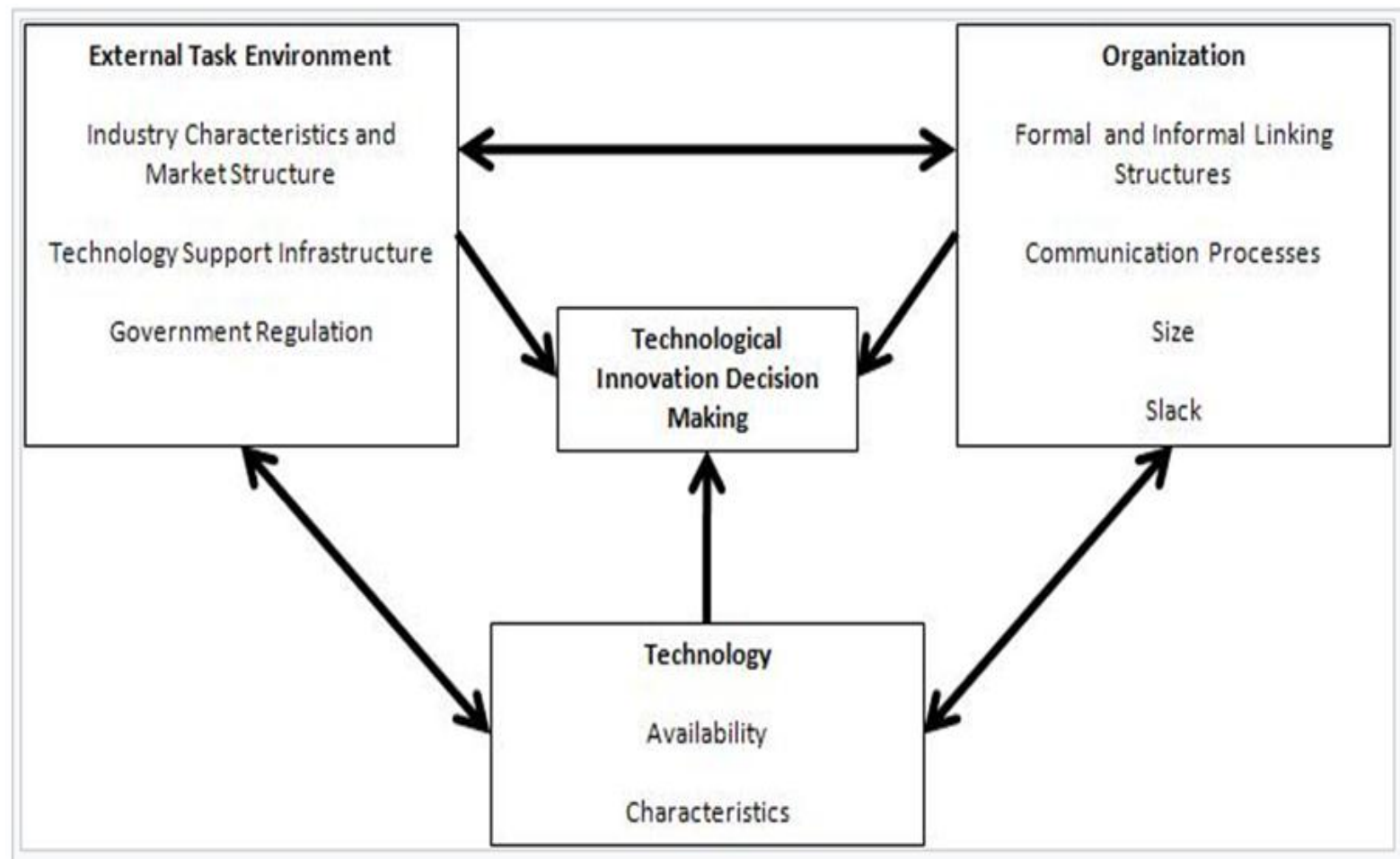

Figure-1. The TOE Model developed by Tornatzky and Fleischer (1990).

Source: Tornatzky and Fleischer (1990)

By technological context, an institution considers the internal and external technologies that are essential and relevant to the day-to-day running of the institutional core services or activities. The organizational context refers to the features and resources possessed by the institution that can influence the decision to adopt technological innovations; this includes the strength or size of the institution, level of centralization, managerial structure, and human resources at its disposal, among others. The environmental context has to do with the scope and structure of the institution, the institution's competitors, and the supervisory environment (Tornatzky \& Fleischer, 1990).

The implication of the TOE theory to this study would not only help understand the major influence of technological adoption in higher education, but also help to determine whether it would facilitate or restrain a higher education institution from embracing opportunities for technological advancement or innovation (Baker, 2016). However, the extent which an institution can invest in its technological learning spaces is determined by the size of the institution; the resources that it possesses or controls; the mindset and skills of its manpower, both academic and non-academic; the perception of the management about the type of graduates that they want to produce, as well as the availability of policy or regulatory bodies to drive technological innovations.

\section{METHODOLOGY}

\subsection{Research Design, Instrument and Data Collection Method}

This study adopts a qualitative research design. Data were collected from eight academic staff members of a comprehensive university in South Africa, through focus group interviews to allow for rich descriptions of the true state of technological space of learning in the institution. The interviews conducted for the selected academic staff were tape-recorded with the consent of the participants. The focus group interviews covered series of topics such as the state of technological learning spaces in the institution, availability and reliability of internet facilities to the 
staff and students, the impact of technological learning spaces to the teaching and learning well-being of both student and staff of the institutions, challenges associated with the available technological spaces, and suggestions for improvement.

\subsection{Sampling}

Semi-structured interviews with eight academic staff members from different academic disciplines within the institution, located in the KwaZulu Natal province of South Africa, were used for this study. The academic experiences of the participants varied from five to twenty years. A convenient sampling method was used to select the participants, aiming to get a maximal variation sample when it comes to gender, experience, education and subject (Creswell \& Creswell, 2017). All the participants were seasoned academicians with good teaching experience, and with adequate knowledge about the state of technological space of an institution.

\subsection{Data Analysis}

The data collected through the tape-recorded interviews were transcribed into texts. The large amounts of transcribed data were studied to identify patterns and inconsistencies. This identification of patterns of participant responses led to the building of broad themes, and sub-themes to address the key research issues raised in the study. Thus, thematic analysis shaped the presentation of empirical data and findings of the study.

\subsection{Ethical Considerations and Trustworthiness}

Resnik (2015) viewed ethics in research as a method, procedure, or basis for deciding how and when to act, and for analysing complex issues associated with research. The participants were guaranteed that the data obtained would be treated with the utmost confidentiality and that the results of the findings would be used for research purposes only. Similarly, to ensure that the participants felt safe, they were not required to give their names, addresses and other personal information while answering questions during the interviews. The findings of the study were also reported in such a way that the participants' identity could not be traceable. It is also noteworthy that before data collection, the researchers secured ethical clearance from the institution where the participants were drawn from. Trustworthiness in qualitative research centers on validity and reliability as a crucial part. Collected data were analyzed and interpreted continuously until they represented the views of the participants.

\section{FINDINGS}

The findings were presented based on three major factors that were identified as themes which included state of technological learning spaces, the impact of technological learning spaces on teaching and learning, and suggestions to improve the technological learning facilities of the institution.

\subsection{Availability and State of the Technological Learning Space}

When the participants were requested to remark on the state of technological learning facilities in their institution, they gave diverse responses. Examples mentioned of the key technological learning facilities included internet connectivity, computer sets, public address systems in the lecture theatres, and Computer/information technology laboratories. All the participants responded affirmatively on the availability of the aforementioned facilities in their institution. However, they expressed their dissatisfaction on the inadequacies of these facilities as revealed in following verbatim remarks of some of the participants:

P1: One of the two computer laboratories we have here has the capacity to host 165 students on workstations and it has got two large smart boards inside where half of the class on the other end have clear systems and visibility and is visible to everybody. 
P2: I would like to maybe comment on the Wi-Fi, I think measures have been put in place and we do really appreciate that especially along the corridors and so on, but I think the students' Wi-Fi is not so strong and easily accessible to them, because what I noticed instead of students sitting in proper learning environments that are conducive for them to study, you see them loitering around and sitting along the steps and they claim that that's where the strong Wi-Fi is accessible. So, I'm not very good when it comes to technology and this Wi-Fi thing, but maybe they should increase the range or maybe have more areas for students to gain easy access.

P3: Computers in the computer laboratories here are inadequate when compared with the number of students enrolled. Sometimes one finds the computer laboratories filled with so many people doing unacceptable things.

P4: With regard to the use of Moodle LMS, I think there is a lot of activity that is taking place in there; even here in our own Faculty, there is a lot of activity. We are only glad that we have colleagues who are willing to assist the academics that are not able to navigate through the system"

The findings, based on the responses of the participants, also revealed that the university has integrated elearning technologies into its teaching and learning process, with the adoption of Moodle as the major Learning Management System (LMS). However, there are obvious challenges that need to be addressed, especially regarding the Wi-Fi connectivity, and its availability to students beyond the lecture halls and office premises.

\subsection{Impact of Technological Learning Spaces on Teaching and Learning}

There is no doubt about the role that technology plays in today's teaching and learning, especially in higher education institutions. Since the participants are seasoned academics in their institution, it was assumed that they must have used or interacted with learning technologies in their institution. The participants had these perceptions about the ways and manners that technological learning spaces made impact on their teaching and learning:

P2: Regarding lecturers, I think there is an issue regarding access to the internet as well. You know, sometimes during the day; the Wi-Fi just goes off and then our environment is such that without WiFi we cannot really do much; we are restricted to emails and so on. Maybe we should have a backup system or a system that is stronger.

P6: There are areas where students struggle to connect to the internet. Ample time is wasted by the students searching for the internet. The majority of the students always roam around to find a spot for accessing the internet.

P7: The microphones in the lecture theatres do not work most of the time. The projector was completely ripped off in one of the lecture theatres that I was allocated for this year with the smartboard cut. It seems that there is no ownership from students.

The major challenges highlighted by the study participants regarding the technological learning spaces in their respective institutions were majorly about equipment such as microphone, WIFI radio, and multimedia projector

\subsection{Improving on the Technological Learning Facilities}

Concerning the question of augmenting the institutions' technological learning spaces, all the participants agreed on the need to improve on the existing technological learning facilities to enhance teaching and learning activities in the institution:

P5: It would make sense if our classrooms could be limited to a maximum of 60 students so that the students can hear the lecturer even if the microphone is not working. Because as things stand now, I don't think we are really being effective.

P6: The classes that I teach is a large one. Though there is a smart board in the lecture theatre, it's not always feasible visible to the students at the back of the class. I have seen institutions having a smart board 
in the middle, and then 2 bigger screens will project. This makes whatever you do on the smartboard to reflect on the bigger screens for students at the back of the class to see.

P7: I would like to see a situation where every student has a digital device that can access the internet through the university Wi-Fi. If you ask them questions, they can type on the device and it appears immediately on the board and we can have a discussion around that.

P8: I want to see a situation where I can invite an expert from another University and I can like Skype, and that person can come into my lecture and can interact with the students right there in at that specific time and students can interact, ask questions and that person is live. I can invite him; I can tell him that he can be part of the lecture. Those things do not exist yet, but that is what I see.

It is interesting to note that all the academics that participated in this study had suggestions that could improve the technological learning spaces in higher education institutions as reflected in their responses. Technological spaces have come to stay as essential facilities that any academic institution must have to be efficient in its day-to-day running. Universities in South Africa use technological software not only for teaching and learning but also to control and manage students' information and data, register students' courses from admission to graduation. Example of this is the adoption of Integrated Tertiary Software (ITS) by most of the higher education institutions in the country.

\section{DISCUSSION OF FINDINGS}

The findings revealed that the university has integrated e-learning technologies into its teaching and learning process, with the adoption of Moodle as the major Learning Management System (LMS). However, there is a challenge with Wi-Fi connectivity beyond the lecture halls and office premises to continue with the learning process. Universities, either conventional or distance-learning based, cannot afford not to embrace e-learning technologies in this era of robotic and artificial intelligence. The recent outbreak of COVID-19 pandemic with its attendant closure of schools worldwide has also proved e-learning to be the only alternative mode to sustain teaching and learning activities. The nature of online learning is such that students can access educational resources through their iPads, tablets, smartphones and laptops at any time and place This requires universities to provide reliable Wi-Fi throughout campus and critical learning spaces. Maphalala and Mpofu (2018) argue that the improvement of technology infrastructure and internet accessibility is critical as this enables successful integration of e-learning into the curriculum. The findings also reveal that the university had neglected its technological learning facilities, to an extent that it no longer benefits. Serious attention should be given to digital learning infrastructures so that they can enhance teaching and learning activities in the institution. The results of this study is consistent with the findings of a study by Twinomugisha, Magochi, and Aluoch (2004) which revealed that internet connectivity in tertiary institutions in Africa is inadequate, expensive and poorly managed. This situation has not significantly improved in 2020 since then. Qureshi, Ilyas, Yasmin, and Whitty (2012) argue that learning and technology go hand in hand; whereby the absence of any one of the factors would greatly diminish the educational value of e-learning.

Participants also highlighted some challenges that are hindering the effective utilization of technological learning spaces in their institutions. It was glaring from their responses that those challenges are causing frustrations and job dissatisfaction on the part of the academics. According to Ngcamu (2019) "Universities across the globe are competing for students, attracting quality staffing and funding with their clear focus to those who leverage new digital capabilities". This is both a challenge and a call for action for the developing universities in South Africa to upgrade their teaching and learning methods by investing in technological learning spaces. Academics with requisite qualifications and skills will not hesitate to leave such environment where the necessary tools to work are not available; perhaps the reason why there is a high rate of migration of academics from the lessresourced universities to the highly resourced ones in the country. 


\section{CONCLUSION AND RECOMMENDATIONS}

Higher education institutions need to take advantage of the fact that many students already have devices like iPads, tablets, smartphones, but none of these can be used without Wi-Fi access. Without reliable Wi-Fi connectivity by institutions, these devices and technologies cannot enhance online learning. Higher education institutions need to invest in ICT to enable students and staff to connect online with ease, throughout the university, including learning spaces and residences as learning continues beyond face-to-face interaction. Adequate facilities also need to be provided for the number of students enrolled in the institution. This should include key technological learning facilities such as computers, public address systems in the lecture theatres, and computer laboratories. Internet connectivity needs to be prioritized in higher education to leverage on the benefits of ICT to enhance learning.

\section{LIMITATIONS OF THE STUDY}

This study explored the dynamics of technological learning spaces as they affect teaching and learning in higher education institutions, using a rural-based university in South Africa as a case study. Though the study made some certain conclusions it is important to note its limitations too, so that the readers can view it in the correct context in which it was conducted.

a. The number of Academics (eight) sampled may not be the true representation of the entire academic staff in the university selected for this study. It is important to note that the institution selected for this study had four faculties but only academics from the faculty of education were sampled as participants for this study.

b. The study covers just one university from the rural part of KwaZulu Natal Province in South Africa. It is, therefore, important for future researchers to examine the technological learning spaces as it affects teaching and learning in other universities in South Africa or even in Africa as a whole.

Funding: This study received no specific financial support.

Competing Interests: The authors declare that they have no competing interests.

Acknowledgement: Both authors contributed equally to the conception and design of the study.

\section{REFERENCES}

Aldiab, A., Chowdhury, H., Kootsookos, A., Alam, F., \& Allhibi, H. (2019). Utilization of learning management systems (LMSs) in higher education system: A case review for Saudi Arabia. Energy Procedia, 160, 731-737.Available at: https://doi.org/10.1016/j.egypro.2019.02.186.

Baker, J. (2016). Technology-organization-environment framework. Retrieved from: https://is.theorizeit.org/wiki/Technologyorganization-environment_framework. [Accessed 11/11/2019].

Brown, M., Dehoney, J., \& Millichap, N. (2015). The next generation digital learning environment. A Report on Research. ELI Paper. Louisville, CO: Educause April, 5(1), 1-13.

Butler-Adam, J. (2018). The fourth industrial revolution and education. South African Journal of Science, 114(5-6), 1-1.

Creswell, J. W., \& Creswell, J. D. (2017). Research design: Qualitative, quantitative, and mixed methods approaches: Sage Publications.

DoBE. (2014). Action plan to 2014: Towards the realisation of schooling 2025. Retrieved from http://www.education.gov.za/Curriculum/ActionPlanto2014/tabid/418/Default.aspx. [Accessed 20/07/2020].

Duvivier, R. J. (2019). How to 'future-proof the use of space in universities by integrating new digital technologies. Perspectives: Policy and Practice in Higher Education, 23(1), 18-23.Available at: https://doi.org/10.1080/13603108.2018.1486894.

Gandhi, M. (2018). A double-edged sword-thoughts on the massification of higher education in India. In Massification of Higher Education in Asia (pp. 57-77). Singapore: Springer.

Garcia, J. D. C., Terol, C. M., Nieto, M., Lledo, A., Sanchez, S., Martin-Aragon, M., \& Sitges, E. (2008). Use and abuse of the Internet in university students. Adicciones, 2O(2), 131-142. 
Gutenberg, J. (2019). The effects of the Internet on learning in higher education. Retrieved from: https://www.eurekalert.org/pub_releases/2019-05/jgum-teo052719.php. [Accessed 08/11/2019].

Keerberg, A., Kiisla, A., \& Mäeltsemees, S. (2013). University implementing its community service role through curriculum development in a regional college. Discussions on Estonian Economic Policy: Topical issues of economic policy in the European $\operatorname{Union}(2)$.

Lall, S., \& Kraemer-Mbula, E. (2005). Structural factors in competitiveness: Technology, skills, and FDI. In Industrial Competitiveness in Africa: Lessons from East Asia (pp. 75-92): Practical Action Publishing.

Lemmens, J.-C., \& Henn, M. (2016). Learning analytics: A South African higher education perspective. Institutional Research in South African Higher Education: Intersecting Contexts and Practices, 231-253.Available at: https://doi.org/10.18820/9781928357186/12.

Ma'arop, A. H., \& Embi, M. A. (2016). Implementation of blended learning in higher learning institutions: A review of the literature. International Education Studies, 9(3), 41-52.Available at: https://doi.org/10.5539/ies.v9n3p41.

Maphalala, M. C., \& Mpofu, N. (2018). Exploring the e-learning experiences of academic staff at a South African University. Progressio, 4O(1), 1-18.Available at: https://doi.org/10.25159/0256-8853/4710.

Marais, P. (2016). "We can't believe what we see": Overcrowded classrooms through the eyes of student teachers. South African Journal of Education, 36(2), 1-10.

McLoughlin, C., \& Lee, M. J. (2008). Future learning landscapes: Transforming pedagogy through social software. Innovate: Journal of Online Education, 4(5), 1-9.

Mohamedbhai, G. (2008). The effects of massification on higher education in Africa. Retrieved from: http://hdl.voced.edu.au/10707/320937. [Accessed 08/11/2019].

Ng'ambi, D., Brown, C., Bozalek, V., Gachago, D., \& Wood, D. (2016). Technology enhanced teaching and learning in South African higher education-A rearview of a 20 year journey. British Journal of Educational Technology, 47(5), 843858.Available at: https://doi.org/10.1111/bjet. 12485.

Ngcamu, B. S. (2019). Digitalizing South African universities: Exploring benefits, barriers and risks Digital Leadership-A New Leadership Style for the 21 st Century: IntechOpen.

Okaz, A. A. (2015). Integrating blended learning in higher education. Procedia-Social and Behavioral Sciences, 186(13), 600603.Available at: https://doi.org/10.1016/j.sbspro.2015.04.086.

Olaniran, S. O., Duma, M. A. N., \& Nzima, D. R. (2017). Assessing the utilization level of E-learning resources among ODL based pre-service teacher trainees. Electronic Journal of e-Learning, 15(5), 384-394.

Pucciarelli, F., \& Kaplan, A. (2016). Competition and strategy in higher education: Managing complexity and uncertainty. Business Horizons, 59(3), 31 1-320.Available at: https://doi.org/10.1016/j.bushor.2016.01.003.

Punie, Y. (2007). Learning spaces: An ICT-enabled model of future learning in the knowledge-based society. European Journal of Education, 42(2), 185-199.

Qureshi, I. A., Ilyas, K., Yasmin, R., \& Whitty, M. (2012). Challenges of implementing e-learning in a Pakistani university. Knowledge Management \& E-Learning: An International Journal, 4(3), 310-324.Available at: https://doi.org/10.34105/j.kmel.2012.04.025.

Reid, L. (2019). Learning management systems: The game changer for traditional teaching and learning at adult and higher education institutions. Global Journal of Human Social Science: G Linguistics \& Education, 19(6), 1-14.Available at: https://doi.org/10.34257/gjhssgvol19is6pg 1.

Resnik, D. B. (2015). What is ethics in research \& why is it important? National Institute of Environmental Health Sciences. Retrieved from https://www.niehs.nih.gov/research/resources/bioethics/whatis/index.cfm.

Selamat, A., Alias, R. A., Hikmi, S. N., Puteh, M., \& Tapsi, S. (2017). Higher education 4.0: Current status and readiness in meeting the fourth industrial revolution challenges. Redesigning Higher Education towards Industry, 4, 23-24.

Servidio, R. (2017). Assessing the psychometric properties of the internet addiction test: A study on a sample of Italian university students. Computers in Human Behavior, 68, 17-29.Available at: https://doi.org/10.1016/j.chb.2016.11.019. 
Sosibo, Z. (2019). Students' perceptions of availability of infrastructure and resources in a Faculty of Education: A transformative agenda.

Tikadar, S., Bhattacharya, S., \& Tamarapalli, V. (2018). A blended learning platform to improve teaching-learning experience. Paper presented at the 2018 IEEE 18th International Conference on Advanced Learning Technologies (ICALT). IEEE.

Tornatzky, L. G., \& Fleischer, M. (1990). The processes of technological innovation. Lexington, Massachusetts: Lexington Books.

Twinomugisha, A., Magochi, J., \& Aluoch, S. (2004). Investigation of bandwidth consolidationfor partnership universities. Nairobi: The African Virtual University.

Views and opinions expressed in this article are the views and opinions of the author(s), International Journal of Education and Practice shall not be responsible or answerable for any loss, damage or liability etc. caused in relation to/arising out of the use of the content. 